\title{
Bid chimeras indicate that most BH3-only proteins can directly activate Bak and Bax, and show no preference for Bak versus Bax
}

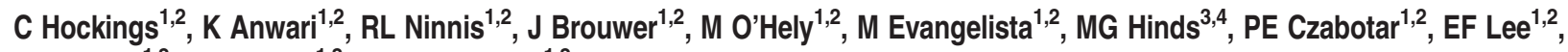 \\ WD Fairlie ${ }^{1,2}$, G Dewson $^{1,2}$ and RM Kluck ${ }^{\star, 1,2}$
}

The mitochondrial pathway of apoptosis is initiated by $\mathrm{Bcl}-2$ homology region 3 (BH3)-only members of the Bcl-2 protein family. On upregulation or activation, certain BH3-only proteins can directly bind and activate Bak and Bax to induce conformation change, oligomerization and pore formation in mitochondria. BH3-only proteins, with the exception of Bid, are intrinsically disordered and therefore, functional studies often utilize peptides based on just their BH3 domains. However, these reagents do not possess the hydrophobic membrane targeting domains found on the native BH3-only molecule. To generate each BH3-only protein as a recombinant protein that could efficiently target mitochondria, we developed recombinant Bid chimeras in which the BH3 domain was replaced with that of other BH3-only proteins (Bim, Puma, Noxa, Bad, Bmf, Bik and Hrk). The chimeras were stable following purification, and each immunoprecipitated with full-length Bcl- $\mathrm{x}_{\mathrm{L}}$ according to the specificity reported for the related $\mathrm{BH} 3$ peptide. When tested for activation of Bak and Bax in mitochondrial permeabilization assays, Bid chimeras were $\sim 1000$-fold more effective than the related BH3 peptides. BH3 sequences from Bid and Bim were the strongest activators, followed by Puma, Hrk, Bmf and Bik, while Bad and Noxa were not activators. Notably, chimeras and peptides showed no apparent preference for activating Bak or Bax. In addition, within the BH3 domain, the h0 position recently found to be important for Bax activation, was important also for Bak activation. Together, our data with full-length proteins indicate that most BH3-only proteins can directly activate both Bak and Bax. Cell Death and Disease (2015) 6, e1735; doi:10.1038/cddis.2015.105; published online 23 April 2015

The $\mathrm{Bcl}-2$ family of proteins controls the mitochondrial pathway of apoptosis, a process often dysregulated in cancer and other diseases. ${ }^{1-3}$ Apoptotic triggers including DNA damage and oncogene activation cause the synthesis or activation of one or more pro-apoptotic $\mathrm{Bcl}-2$ homology region 3 (BH3)-only proteins, ${ }^{1-4}$ a subfamily that includes Bid, Bim, Puma, Noxa, $\mathrm{Bad}, \mathrm{Bik}, \mathrm{Bmf}$ and Hrk. These proteins then engage via their $\mathrm{BH} 3$ domain with other Bcl-2 family members. BH3-only proteins that can directly bind and activate the $\mathrm{Bcl}-2$ effector proteins Bak or Bax are called 'activators' ${ }^{5}$ When Bak or Bax become activated and oligomerize in the mitochondrial outer membrane (MOM), the apoptotic 'switch' has flipped and the cell is committed to cell death. The prosurvival members (Bcl2, Bcl- $\mathrm{X}_{\mathrm{L}}, \mathrm{Mcl}-1, \mathrm{Bcl}-\mathrm{w}, \mathrm{Bfl}-1 / \mathrm{A} 1$ and $\mathrm{Bcl}-\mathrm{B}$ ) inhibit apoptosis by specifically binding both the $\mathrm{BH} 3-$ only proteins and activated Bak and Bax. ${ }^{6-11}$ Thus, the cell's complement of prosurvival proteins, Bak, and Bax, determines the sensitivity of that cell to each BH3-only protein, and by extension to each type of proapoptotic stimulus.

A thorough understanding of $\mathrm{BH} 3$-only proteins is crucial for the development of cancer therapeutics such as the new class of anti-cancer molecules called $\mathrm{BH} 3$ mimetics that are showing significant promise in clinical trials. ${ }^{12,13}$ The binding of $\mathrm{BH} 3-$ only proteins to prosurvival proteins has been wellcharacterized and revealed significant preferences for engaging different members. ${ }^{6,8,9}$ How $\mathrm{BH} 3$-only proteins bind and activate Bak and Bax remains less understood for several reasons. First, generating stable recombinant $\mathrm{BH}$-only proteins is difficult because, except for Bid, they are intrinsically disordered ${ }^{14-16}$ and because most contain hydrophobic C-terminal membrane anchors. ${ }^{17}$ Thus, most in vitro studies of BH3-only proteins have used synthetic peptides corresponding to the $\mathrm{BH} 3$ domains, C-terminally truncated recombinant proteins or in vitro translated (IVT) proteins. Second, BH3-only reagents bind poorly to recombinant Bak and Bax in the absence of membranes, although detergents and liposomes may substitute for the MOM. ${ }^{18-20}$ Third, activation of Bak and Bax on mitochondria can be complicated by the presence of other proteins such as prosurvival proteins. Indeed, genetically altering BH3-only protein levels in mice resulted in complex phenotypes due to multiple interactions between family members, precluding firm conclusions as to which BH3-only proteins are direct activators. ${ }^{18,21,22}$

\footnotetext{
${ }^{1}$ The Walter and Eliza Hall Institute of Medical Research, 1 G Royal Parade, Parkville, Victoria 3052, Australia; ${ }^{2}$ Department of Medical Biology, The University of Melbourne, Parkville, Victoria 3010, Australia and ${ }^{3}$ School of Chemistry and Bio21 Molecular Science and Biotechnology Institute, University of Melbourne, Parkville, Victoria 3010, Australia

*Corresponding author: RM Kluck, Walter and Eliza Hall Institute of Medical Research, 1G Royal Parade, Parkville, Melbourne, Victoria 3052, Australia. Tel: +61 393452487 ; Fax: +61 39347 0852; E-mail: kluck@wehi.edu.au

${ }^{4}$ Present address: Department of Chemistry and Physics, La Trobe Institute for Molecular Science, La Trobe University, Bundoora, Victoria 3086, Australia. Abbreviations: $\mathrm{BH} 3, \mathrm{Bcl}-2$ homology region 3; HA, haemagglutinin; IVT, in vitro translated; MLM, mouse liver mitochondria; MOM, mitochondrial outer membrane; SDS, sodium dodecyl sulfate; SPR, surface plasmon resonance; TBS, Tris buffered saline

Received 11.8.14; revised 17.3.15; accepted 17.3.15; Edited by T Kaufmann
} 
Bid and Bim are direct activators according to a variety of approaches, $5,8,9,23,24$ and were recently proposed to be specific for Bak and Bax, respectively. ${ }^{25}$ Early studies using Noxa BH3 peptides ${ }^{5,8}$ and IVT Noxa ${ }^{9}$ concluded that Noxa was not an activator. However, in more recent studies a Noxa $\mathrm{BH} 3$ peptide $^{23}$ and purified recombinant Noxa $\Delta \mathrm{C}^{20}$ were found to be activators of both Bak and Bax. Puma has also been described as both an activator ${ }^{26,27}$ and not an activator. ${ }^{8,28} \mathrm{Du}$ et $a l^{23}$ analyzed the full panel of $\mathrm{BH} 3$ peptides and classified Bim as a strong activator, Bid, Noxa and Bmf as moderate activators, and Puma, Bik and Hrk as weak activators. The only BH3-only member that has never been described as an activator is Bad.

While $\mathrm{BH} 3$ peptides and recombinant truncated $\mathrm{BH} 3$-only proteins have been useful for in vitro studies, new reagents that target mitochondria may better reflect the behavior of the parent proteins. As Bid is stable as a recombinant protein, we generated chimeras of $\mathrm{Bid}$ in which the $\mathrm{BH} 3$ domain of Bid was replaced with that of seven other $\mathrm{BH} 3-$ only proteins. This is a similar approach to the Bim chimeras used for expression in cells ${ }^{18}$ and in mice. ${ }^{29}$ More recently, truncated Bid (tBid) chimeras containing the $\mathrm{BH} 3$ domains of $\mathrm{Bim}$, Bak and Bax as well as those of the prosurvival proteins, have been generated as IVT proteins. ${ }^{11}$

To compare the ability of $\mathrm{BH} 3$-only proteins to activate Bak and $\mathrm{Bax}$ in vitro, we incubated Bid chimeras and $\mathrm{BH} 3$ peptides with mitochondria containing either Bak or Bax. We found that the membrane-targeted Bid chimeras were much more potent activators than their related $\mathrm{BH} 3$ peptides, and that all $\mathrm{BH} 3$ domains except for Bad and Noxa were activators to some extent. We conclude that activation of Bak and Bax may be underestimated by studies using $\mathrm{BH} 3$ peptides, and that even BH3-only proteins such as Bik, Bmf and Hrk that are often considered unable to activate Bak or Bax, may act as activators under certain conditions.

\section{Results}

Bid BH3 chimeras are stable as recombinant proteins. $\mathrm{Bid}$ is the only $\mathrm{BH} 3$-only protein that can be readily expressed and purified as a recombinant protein. To generate stable proteins that mimic the behavior of the other BH3-only proteins the $\mathrm{BH} 3$ domain of human Bid (residues 81-100) was replaced with the $\mathrm{BH} 3$ domains of 7 other human $\mathrm{BH} 3-$ only proteins to create the $\mathrm{Bid}^{\mathrm{Bim}}, \mathrm{Bid}^{\mathrm{Puma}}, \mathrm{Bid}^{\text {Noxa }}, \mathrm{Bid}^{\mathrm{Bad}}$, $\mathrm{Bid}^{\mathrm{Bik}}, \mathrm{Bid}^{\mathrm{Bmf}}$ and Bid ${ }^{\mathrm{Hrk}}$ chimeras (Figure 1a). Bid chimeras containing the $\mathrm{BH} 3$ domains of Bak and Bax were also generated to explore Bak and Bax function, and to allow comparison with the $\mathrm{tBid}^{\mathrm{Bax}}$ and $\mathrm{Bid}^{\mathrm{Bak}}$ chimeras reported previously. ${ }^{11}$ To simplify purification, the caspase-8 cleavage site in Bid was replaced with a thrombin cleavage site, allowing a combined cleavage/purification step. ${ }^{30}$ Thus, all Bid chimeras presented in this study are 'cleaved' Bid (also called $\mathrm{n} / \mathrm{cBid}$ or $\mathrm{p} 7 / \mathrm{p} 15 \mathrm{Bid}$ ). A C-terminal haemagglutinin (HA) tag was added to detect chimeras by immunoblotting, and shown not to affect function (Supplementary Figure 1). The swapped $\mathrm{BH} 3$ region was initially 20 residues covering the 4 hydrophobic residues (h1-h4) important for binding to prosurvival proteins ${ }^{31}$ and the 2 hydrophobic residues (h0)

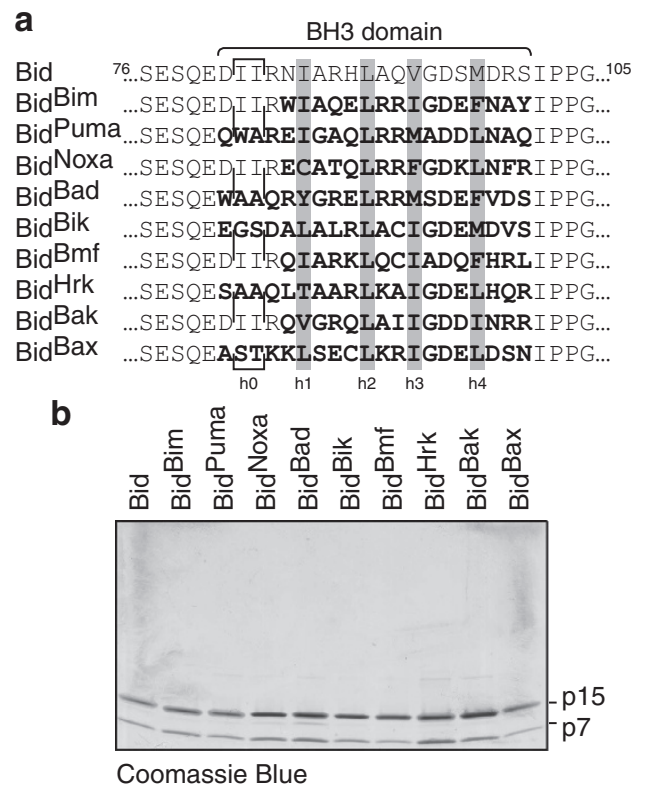

Figure 1 Bid BH3 chimeras are stable recombinant proteins. (a) Sequence of Bid $\mathrm{BH} 3$ chimeras. Sequence alignment shows the Bid $\mathrm{BH} 3$ domain swapped for that of other Bcl-2 family members. Hydrophobic residues (h1-h4) that are important for binding to prosurvival proteins ${ }^{31}$ are highlighted, as are the recently identified ho residues that are important for binding to Bax. ${ }^{24}$ (b) Recombinant Bid BH3 chimeras. Chimeras were cleaved by thrombin during purification to generate $\mathrm{N}$-terminal $\mathrm{p} 7$ and C-terminal $p 15$ fragments of Bid. ${ }^{30}$ Chimeras were separated by SDS-PAGE and stained for total protein

recently shown to be important for binding to Bax. ${ }^{24}$ However, four of the chimeras (those with Bim, Noxa, Bmf and Bak BH3 domains) expressed poorly or aggregated during purification (not shown). This may be due to residues that correspond to 183 in Bid (glutamate from Bim, Noxa and Bmf or methionine from Bak, Supplementary Figure 2a) being poorly tolerated. 183 normally makes contact with four hydrophobic residues in helices 1 and 8 that may stabilize the protein (Supplementary Figure 2b). ${ }^{32}$ Accordingly, when the swapped domain was shortened to 16 residues to retain 183 , the 4 chimeras were stable (Figure 1b). As expected, the p15 fragments of all Bid chimeras retained the ability to translocate to membranes of mouse liver mitochondria (MLM) (Supplementary Figure 2c).

Bid BH3 chimeras exhibit specific binding to prosurvival proteins. To evaluate the Bid $\mathrm{BH} 3$ chimeras, they were first tested for binding to the Bcl- $\mathrm{X}$ p prosurvival protein (Figure 2a and Supplementary Figure 3a). Equimolar chimera and full-length $\mathrm{Bcl}-\mathrm{x}_{\mathrm{L}}$ were incubated in the presence of $\mathrm{Bak}^{-1-} \mathrm{MLM}$, and the immunoprecipitated $\mathrm{Bcl}-\mathrm{x}_{\mathrm{L}}$ examined for bound chimera. Each chimera, except for Bid ${ }^{\text {Noxa }}$, co-precipitated strongly with $\mathrm{Bcl}-\mathrm{x}_{\mathrm{L}}$ (Figure 2a, upper panel), consistent with the binding of human $\mathrm{BH} 3$ peptides to $\mathrm{Bcl}-\mathrm{x}_{\mathrm{L}} \Delta \mathrm{C} 25$ measured by surface plasmon resonance (SPR) (Figure 2a, lower panel). ${ }^{6,7,10}$

C-terminally truncated prosurvival proteins have altered BH3-binding specificity when tested on mitochondria. When C-terminally truncated $\mathrm{BCl}-\mathrm{x}_{\mathrm{L}}(\Delta \mathrm{C})$ was tested for binding to Bid chimeras its specificity was significantly 
a
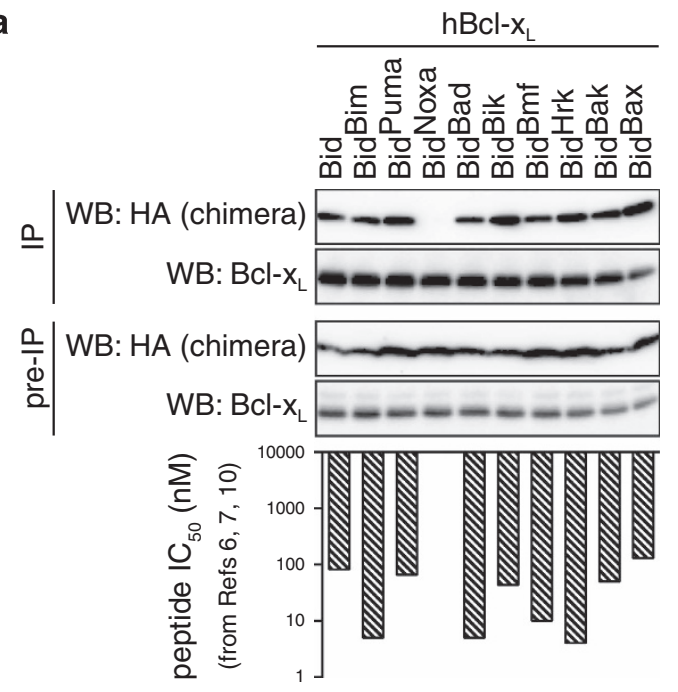

b
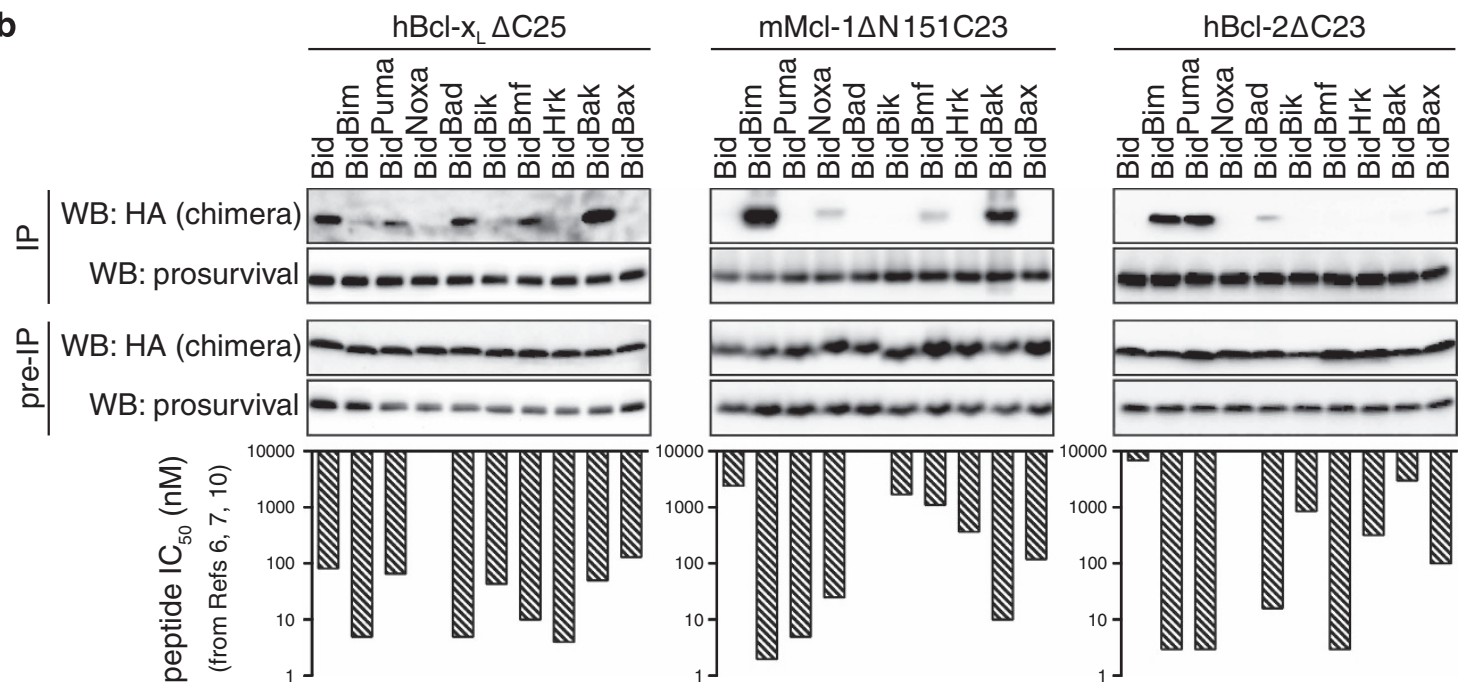

Figure 2 Bid BH3 chimeras show specific binding to prosurvival proteins. (a) Bid BH3 chimeras show specificity in binding to full-length $\mathrm{Bcl}-\mathrm{x}_{\mathrm{L}}$. Bid BH3 chimeras and fulllength $\mathrm{Bcl}-\mathrm{x}_{\mathrm{L}}$ were incubated at a 1:1 molar ratio in the presence of $B a k^{-1-} \mathrm{MLM}$ before solubilization with $1 \%$ digitonin, immunoprecipitation (IP) of $\mathrm{Bcl}-\mathrm{X}_{\mathrm{L}}$ and Western blotting for bound chimera (HA tag). (b) Bid BH3 chimeras binding to truncated Bcl- $\mathrm{x}_{\mathrm{L}}, \mathrm{Mcl}-1$ and $\mathrm{Bcl}-2$. The chimeras were incubated as in (a) with the indicated truncated prosurvival proteins. Blots are representative of three independent experiments (shown in Supplementary Figure 3 a). Bottom panels show previously published IC ${ }_{50}$ values of the equivalent $\mathrm{BH} 3$ peptides for binding to truncated prosurvival proteins as measured by SPR., ${ }^{6,10}$

different to full-length $\mathrm{Bcl}-\mathrm{x}_{\mathrm{L}}$, with four chimeras $\left(\mathrm{Bid}^{\mathrm{Bim}}\right.$, $\mathrm{Bid}^{\mathrm{Bik}}$, Bid ${ }^{\mathrm{Hrk}}$ and $\mathrm{Bid}^{\mathrm{Bax}}$ ) showing little co-precipitation (Figure $2 \mathrm{~b}$ and Supplementary Figure $3 \mathrm{a}$ ). Chimeras bound to the canonical hydrophobic groove in full-length $\mathrm{Bcl}-\mathrm{x}_{\mathrm{L}}$, rather than a site involving the $\mathrm{C}$ terminus, as the $\mathrm{BH} 3$ mimetic ABT-737 prevented co-precipitation (Supplementary Figure $3 b$ ). Altered binding may be due in part to truncated $\mathrm{Bcl}-\mathrm{x}_{\mathrm{L}}$ remaining in the supernatant, whereas full-length $\mathrm{Bcl}-\mathrm{x}_{\mathrm{L}}$ (and Bid chimeras) was predominantly membrane associated (Supplementary Figure $3 \mathrm{c}$ ). Consequently, the hydrophobic groove may adopt a different conformation and therefore binding specificity on membrane insertion.

The chimeras also showed specific binding to truncated Mcl-1 $(\Delta \mathrm{N} \Delta \mathrm{C})$ and to truncated $\mathrm{Bcl}-2(\Delta \mathrm{C})$ (Figure $2 \mathrm{~b}$ and Supplementary Figure $3 a$ ). While binding was similar to that of $\mathrm{BH} 3$ peptides on SPR, there were some exceptions.
For example, Bid ${ }^{\text {Puma }}$ bound poorly to $\mathrm{Mcl}-1 \Delta \mathrm{N} \Delta \mathrm{C}$ and $\mathrm{Bid}^{\mathrm{Bmf}}$ bound poorly to $\mathrm{Bcl}-2 \Delta \mathrm{C}$ (Figure $2 \mathrm{~b}$ ). Thus, membrane insertion may alter the binding profile of several prosurvival proteins.

In the absence of mitochondria, the chimeras immunoprecipitated only weakly with truncated prosurvival proteins (data not shown), consistent with the requirement of membranes for separation of the Bid p7 and p15 fragments and exposure of the Bid $\mathrm{BH} 3$ domain. ${ }^{33-35}$ Accordingly, SPR (which is performed in the absence of membranes) also failed to detect binding of the chimeras to $\mathrm{Bcl}-\mathrm{x}_{\mathrm{L}} \Delta \mathrm{C}$ and $\mathrm{Mcl}-1 \Delta \mathrm{N} \Delta \mathrm{C}$ even in the presence of octyl glucoside (data not shown), a detergent commonly used to separate the p7 and p15 fragments of Bid. ${ }^{36}$

In summary, binding of the chimeras to full-length $\mathrm{Bcl}-\mathrm{x}_{\mathrm{L}}$ (in the presence of mitochondria) reflected the specificity of their cognate $\mathrm{BH} 3$ peptide. In addition, the importance of 
studying full-length $\mathrm{Bcl}-2$ proteins in their native environments was highlighted by the altered binding specificity of Bid chimeras to truncated prosurvival proteins.

Most $\mathrm{BH} 3$ chimeras and peptides activate Bak and Bax, but with different potencies. To compare the ability of each chimera or related $\mathrm{BH} 3$ peptide to activate Bak, wild-type C57BL/6 MLM were incubated with increasing concentrations of chimera or $\mathrm{BH} 3$ peptide and tested for cytochrome $c$ release. To test activation of Bax, MLM from Bak ${ }^{-1-}$ mice were supplemented with recombinant full-length Bax. ${ }^{37} \mathrm{MLM}$ have been used previously to assess Bak and Bax activation $^{11,24,38,39}$ as the remaining $\mathrm{Bcl}-2$ proteins were undetectable except for $\mathrm{Bcl}-\mathrm{x}_{\mathrm{L}}$ which was present at low levels $(<3 \mathrm{nM}) .{ }^{40}$ Cytochrome $c$ release was used as a measure of Bak or Bax activation as the two events correlated strongly in wild-type MLM (Supplementary Figure 1), and no cytochrome $c$ release occurred in $\mathrm{Bak}^{-/-} \mathrm{MLM}$ without addition of Bax (data not shown). ${ }^{5,40,41}$

Most Bid chimeras induced dose-dependent activation of Bak (release of cytochrome $c$ ), allowing estimation of their $\mathrm{EC}_{50}$ (Figure 3a). Similar experiments performed for Bak activation by $\mathrm{BH} 3$ peptides, and for Bax activation by Bid chimeras and peptides, allowed us to compare Bak and Bax activation by both types of reagents (Figure $3 b$ ). Bid and Bid ${ }^{\text {Bim }}$ and the related peptides were strong activators of both Bak and Bax (Figure 3b), consistent with previous reports. ${ }^{5,9,23}$ Bid $^{\text {Puma }}$ chimera and Puma peptide were also activators, in agreement with some $9,23,26,27$ but not other reports. ${ }^{8,28} \mathrm{Bmf}$, Hrk and Bik reagents were activators, with Bik being the weakest. While Bid ${ }^{\text {Noxa }}$ could also activate both Bak and Bax, the Noxa peptide had no apparent activator activity. As Bid ${ }^{\text {Bad }}$ chimera and Bad peptide often failed to completely release cytochrome $c$, the $\mathrm{EC}_{50}$ was not included in Figure $3 \mathrm{~b}$. The Noxa and Bad results are discussed in more detail below. Finally, Bid ${ }^{\text {Bak }}$ and $\mathrm{Bid}^{\mathrm{Bax}}$ chimeras (and equivalent $\mathrm{BH} 3$ domain peptides) could activate both Bak and Bax, as previously reported, ${ }^{11}$ and consistent with Bak and Bax being able to auto-activate. ${ }^{42}$

By comparing both Bak and Bax activation by each chimera and $\mathrm{BH} 3$ peptide, we could draw several conclusions. First, the Bid chimeras were generally $>1000$-fold more potent than their related $\mathrm{BH} 3$ peptide in activating Bak. This was attributable to the Bid scaffold targeting all chimeras to the MOM (Supplementary Figure 2c), consistent with targeting a Bid peptide to liposomes making it nearly as potent as the Bid protein in activating Bax. ${ }^{43}$ The Bid scaffold may also increase the affinity of the $\mathrm{BH} 3$ domain by stabilizing its structure, or by aligning the $\mathrm{BH} 3$ domain to the activation site on Bak and Bax. Second, the chimeras are reasonable mimics of their parent $\mathrm{BH} 3-$ only proteins, as the relative potency of each chimera, with the exception of Noxa, reflected the relative potency of the cognate $\mathrm{BH} 3$ peptide (Figure $3 \mathrm{~b}$ ). Third, the relative potencies of the chimeras for activating Bak and Bax were similar, as were the potencies of the peptides (Figure $3 \mathrm{~b}$ and Supplementary Figure 4). Thus, while BH3-only proteins show specificity for certain prosurvival proteins, they may not for Bak and Bax. In particular, in contrast to a recent report, ${ }^{25}$ there was little evidence of Bid preferentially targeting Bak and
Bim preferentially targeting $\mathrm{Bax}$, as $\mathrm{Bid}^{\mathrm{Bim}}$ was approximately fourfold less potent than Bid in activating both Bak and Bax.

Bad does not directly activate Bak or Bax, but can do so indirectly. Compared with the other $\mathrm{BH} 3-$ only reagents, the $\mathrm{Bid}^{\mathrm{Bad}}$ chimera and Bad peptide caused a more graded and often incomplete release of cytochrome $c$, particularly in the Bax experiments (Figure 4 and Supplementary Figure 5). This made $\mathrm{EC}_{50}$ estimations problematic, and suggested that the Bad-like reagents caused cytochrome $c$ release indirectly (also called de-repression). As Noxa peptide, that does not bind to $\mathrm{Bcl}-\mathrm{x}_{\mathrm{L}}{ }^{6}$ did not cause any cytochrome $c$ release (Figure $3 b$ ), it is possible that the Bad-like reagents bind endogenous $\mathrm{BCl}-\mathrm{x}_{\mathrm{L}}$ present on MLM to liberate endogenous activators that then activate Bak or Bax. Variable cytochrome $c$ release induced by Bad-like reagents (Supplementary Figure 5) might be explained by variation in the levels of $\mathrm{Bcl}-\mathrm{x}_{\mathrm{L}}$ and/or direct activators between mitochondria preparations.

To further test direct activation by the chimeras, they were tested for their ability to activate His-tagged Bak $\Delta C T$ on nickelchelating liposomes (Figure 5), as described previously. ${ }^{44}$ While the dose range (from 1 to $3 \mathrm{nM}$ ) was more limited in this assay to avoid non-specific permeabilization, each chimera except for $\mathrm{Bid}^{\mathrm{Bad}}$ was able to activate Bak and permeabilize the liposomes. Moreover, the activation profile matched that for full-length Bak in MLM (Figures $3 a$ and b), indicating that other Bcl-2 family proteins in MLM probably had little impact on cytochrome $c$ release by all chimeras except $\mathrm{Bid}^{\mathrm{Bad}}$.

Noxa does not directly activate Bak or Bax. The finding that Bid ${ }^{\text {Noxa }}$, but not Noxa peptide, could activate Bak and Bax (Figure 3) prompted us to test a recombinant variant of the Noxa protein (Figure 6a). GST-Noxa $\Delta \mathrm{C}$ contains GST at the $\mathrm{N}$-terminus for increased stability and lacks the C-terminal membrane anchor, similar to a variant of Noxa (S peptideNoxa $\Delta \mathrm{C}$ ) reported to bind and activate $\mathrm{Bak} \Delta \mathrm{C}$ in liposomes. ${ }^{20}$ In the MLM, even very high concentrations $(10 \mu \mathrm{M})$ of GSTNoxa $\Delta \mathrm{C}$ did not activate Bak or Bax (Figure 6a) despite the Noxa $\mathrm{BH} 3$ domain being available for binding to $\mathrm{Mcl}-1$ (Figure 6b).

The Bid ho contributes to Bak and Bax activation. Mutagenesis was then used to examine why the Bid ${ }^{\text {Noxa }}$ chimera activated Bak and Bax, but Noxa peptide and GSTNoxa $\triangle \mathrm{C}$ did not (Figures $3 \mathrm{~b}$ and $6 \mathrm{a}$ ). As noted above, the chimera contains the Bid sequence (QEDIIR) around the h0 region recently found to be important for activating Bax. ${ }^{24}$ To test whether the h0 region might also contribute to Bak activation, and account for the activator activity of Bid ${ }^{\text {Noxa }}$, we replaced the two ho residues in $\mathrm{Bid}^{\text {Noxa }}$ with alanine,

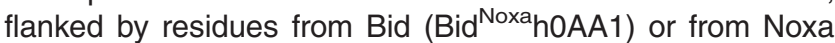

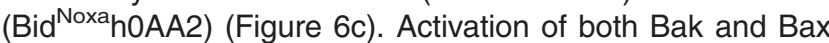
was decreased by $\sim 10$-fold (Figure $6 \mathrm{~d}$ ), indicating that h0 residues contribute to activation of Bak as well as Bax. In the reverse approach, we attempted to convert the Noxa peptide to an activator by adding Bid sequence (Figure 6c). Introducing just the two h0 isoleucines of Bid (Noxa holl peptide) was not sufficient, but introducing seven Bid residues (BidNoxa peptide) to mimic the swap in the Bid ${ }^{\text {Noxa }}$ chimera 
a

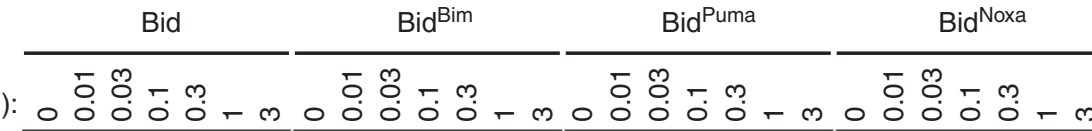
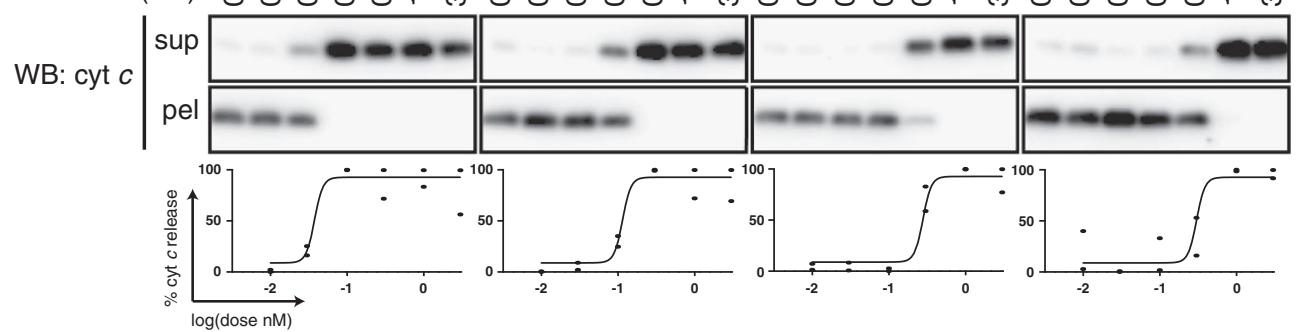

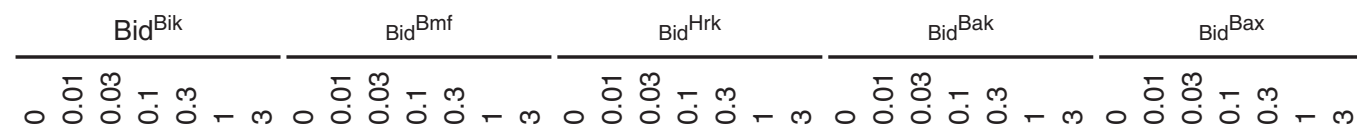

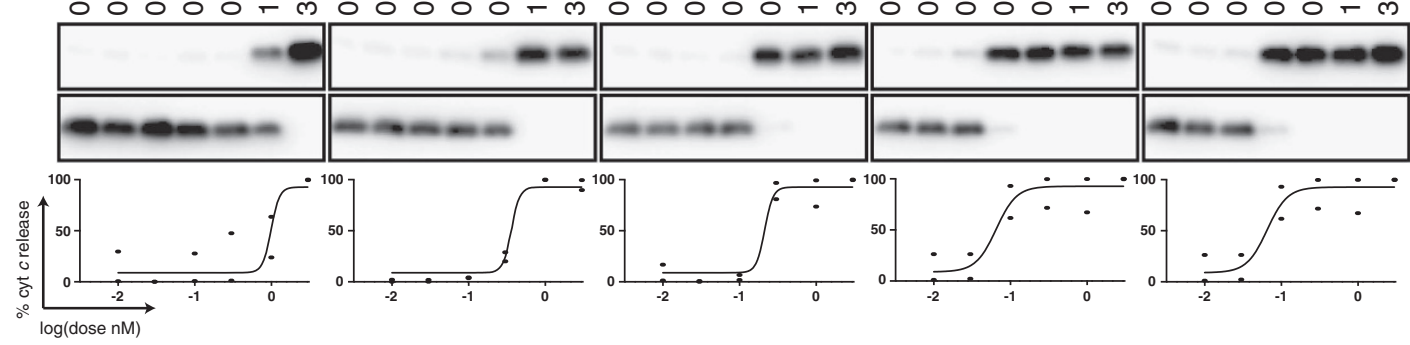

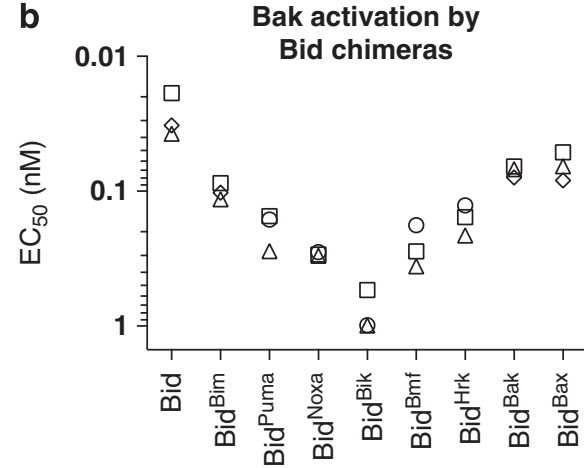

Bax activation by Bid chimeras

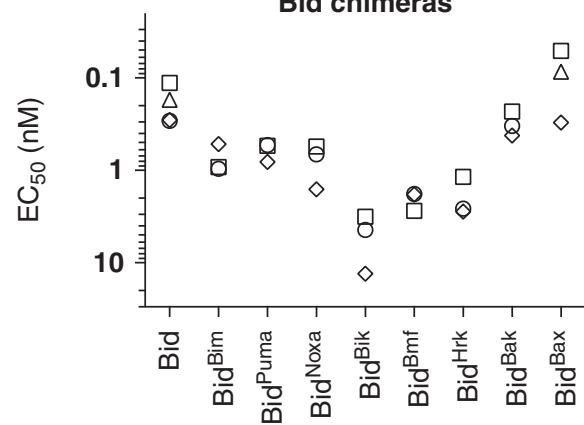

Bak activation by BH3 peptides

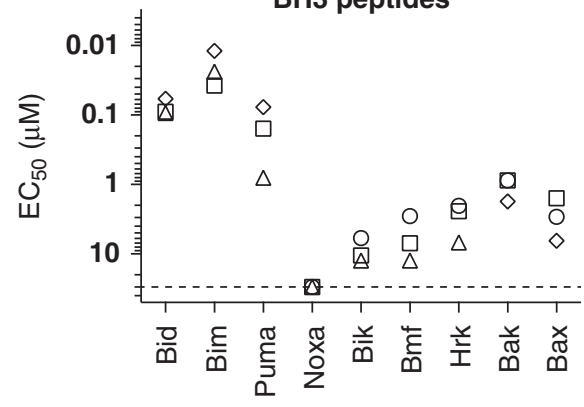

Figure 3 Bid chimeras and BH3 peptides are similar in their specificity for activating both Bak and Bax. (a) Bid chimeras activate Bak to release cytochrome $c$. Wild-type MLM were treated with the indicated Bid chimeras and supernatant (sup) and pellet (pel) fractions Western blotted for cytochrome $c$ (top panels). Quantification of cytochrome $c$ release allowed estimation of $\mathrm{EC}_{50}$ (bottom panels). (b) Comparison of Bak and Bax activation by Bid chimeras and BH3 peptides. Wild-type MLM (Bak activation) or Bak ${ }^{-1-}$ MLM plus $10 \mathrm{nM}$ Bax (Bax activation) were treated with Bid chimeras or BH3 peptide. Cytochrome $c$ release was quantified as in $\mathbf{a}$. The $\mathrm{EC}_{50}$ values from three or four independent experiments are shown, and in each graph the values from one experiment are represented by the same symbol. Note that $E_{50}$ values for Bid ${ }^{B a d}$ and Bad peptide were not estimated because cytochrome $c$ release was often incomplete (see Figure 4) 
now converted the peptide to an activator (Figure 6e). Within those seven Bid residues, the h0 residues were required as their substitution with alanine (BidNoxa h0AA peptide) abrogated Bak activation (Figure 6e). Residues flanking h0 may also promote or hinder activation, as BidNoxa peptide but not Noxa holl peptide could activate Bak and Bax (Figure 6e) and the Bid ${ }^{\text {Noxa }}$ hOAA1 and hOAA2 mutant chimeras did not lose all activator function (Figure 6d). Results with the Noxa peptide are consistent with reduced Bak activation by a Bid peptide in which truncation had removed the h0 region. ${ }^{39}$ In summary, these experiments show that h0 in both peptide and chimera can contribute to Bak activation, as well as Bax activation. ${ }^{24}$

\section{Discussion}

The Bid chimeras were generally $>1000$ times more potent than $\mathrm{BH} 3$ peptides at directly activating Bax/Bak (Figure 3), as previously shown for Bid protein versus Bid BH3 peptide., 83 The potency of the chimeras may be largely due to membrane targeting by the Bid scaffold, as targeting a Bid peptide to mitochondria rendered it almost as potent as Bid protein; ${ }^{43,45}$ induced helicity of the $\mathrm{BH} 3$ domain ${ }^{46,47}$ or improved 'presentation' of the $\mathrm{BH} 3$ domain to Bak or Bax may also contribute. As all BH3-only proteins (except Bad) contain a C-terminal

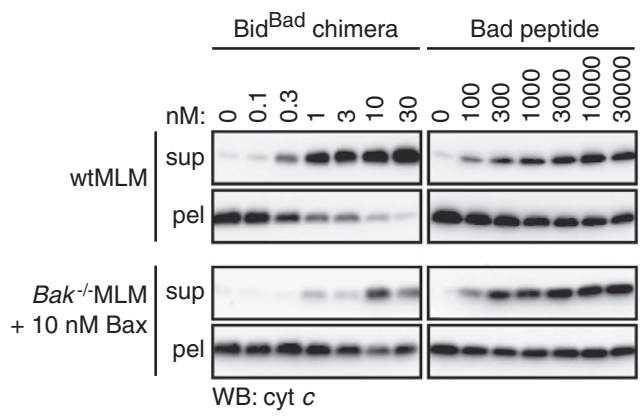

Figure 4 Bad-like reagents often induce only partial cytochrome $c$ release. Wildtype MLM or Bak ${ }^{-1}$ MLM plus $10 \mathrm{nM}$ Bax were treated with Bid ${ }^{\mathrm{Bad}}$ or Bad peptide as in Figure 3 and assessed for cytochrome $c$ release. Blots are representative of at least four independent experiments (shown in Supplementary Figure 5) mitochondrial targeting domain, ${ }^{17}$ they are better represented by the Bid chimeras than by $\mathrm{BH} 3$ peptides. In addition, as tBid (the p15 fragment) becomes intrinsically disordered when bound to membranes, ${ }^{48-51}$ the final tertiary structures of chimeras and parent $\mathrm{BH} 3-$ only proteins may be similar. Thus, previous studies with $\mathrm{BH} 3$ peptides or truncated $\mathrm{BH}$-only proteins may have underestimated the ability of the parent $\mathrm{BH} 3-$ only proteins to activate Bak and Bax, and the Bid chimeras provide an improved means of assessing direct activation.

Our studies indicate that each of the BH3-only proteins, except for Bad and Noxa, have some ability to activate Bak and Bax. Bik, Bmf and Hrk are often considered to be 'sensitizers' that function only by binding and sequestering prosurvival proteins. However, as our data indicate that they may also activate Bak and Bax, both functions may be important, as deduced for Bim in vivo. ${ }^{29}$

Our comparison of Bak and Bax showed that both were activated by the same chimeras, and by the same peptides (Figure 3 and Supplementary Figure 4). This is consistent with liposome studies in which Bak $\Delta \mathrm{N} \Delta \mathrm{C}$ and Bax were activated by the same $\mathrm{BH} 3$ peptides. $^{23}$ Our findings differ from experiments with permeabilized cells (which may contain prosurvival proteins), where Bak was preferentially activated by Bid, while Bax was preferentially activated by Bim. ${ }^{25}$ Our findings are more consistent with their experiments with isolated mitochondria and liposomes where the preference was less apparent. ${ }^{25}$ Finally, the lack of specificity of BH3-only proteins for activating Bak versus Bax, and a role for h0 in activating both Bak and Bax, suggests similar activation sites on both pore-forming proteins. Accordingly, several structures show $\mathrm{BH} 3$ peptides bound to the canonical hydrophobic grooves in Bak and Bax. ${ }^{24,39,52}$

In conclusion, cells have various means of activating Bak and Bax, as most $\mathrm{BH} 3-$ only proteins can directly activate Bak and Bax, and others (Bad and Noxa) may indirectly activate the two proteins. Direct activation is greatly enhanced by targeting to mitochondria, suggesting that studies relying on C-terminally truncated $\mathrm{BH} 3$-only proteins and $\mathrm{BH} 3$ peptides underestimate direct activation by their parent $\mathrm{BH} 3$-proteins. The Bid chimeras developed in this study are targeted to membranes to better represent the interactions between

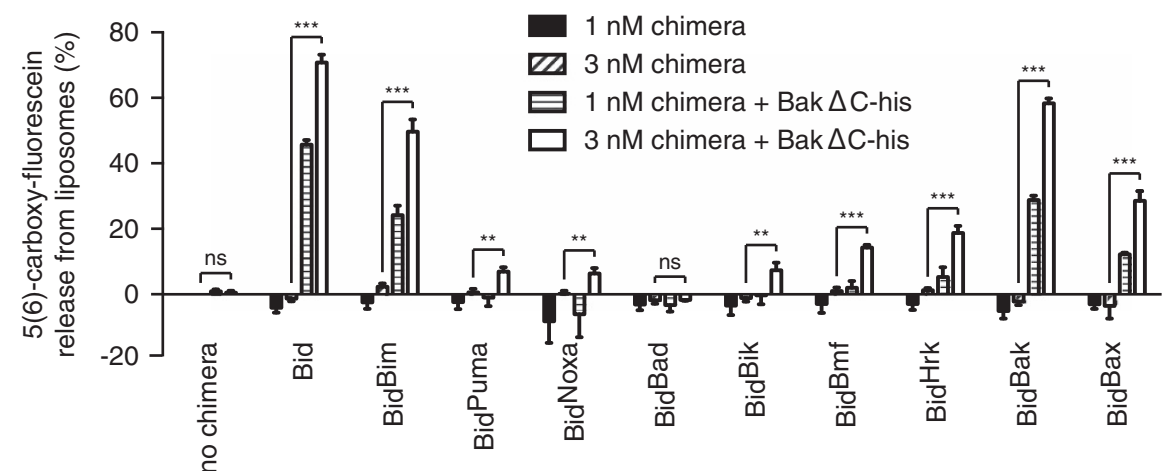

Figure 5 Each Bid chimera, except for Bid ${ }^{\text {Bad }}$, can activate recombinant Bak to permeabilize liposomes. Nickel-chelating liposomes were treated with $150 \mathrm{nM} \mathrm{His-tagged}$ $\mathrm{Bak} \Delta \mathrm{C}$ and Bid chimeras as indicated and tested for the release of 5(6)-carboxy-fluorescein. Data were normalized by subtracting the signal from untreated liposomes, and then expressed as a percentage of the signal induced by permeabilization with $1 \%$ CHAPS. Error bars indicate the S.E.M. of four separate experiments. Statistical significance ('NS' not significant, ${ }^{* \star} P<0.01,{ }^{* \star *} P<0.001$ ) was calculated using non-normalized data and a one-tailed Student's $t$-test 
BH3-only proteins and Bak and Bax that require a membrane. ${ }^{17,33,43}$ Therefore, they are important new tools for in vitro studies of $\mathrm{Bcl}-2$ proteins on liposomes, vesicles or mitochondria.

\section{Materials and Methods}

Generating recombinant proteins and BH3 peptides. Chimeras of human Bid in which the BH3 domain (aa 81-100) was swapped with 20 residues (human Puma 132-151, Bad 105-124, Bik 52-71, Hrk 28-47 and Bax 52-71) or 16 residues (Bid 85-100 replaced with human Bim 147-162, Noxa 24-39, Bmf 170- a

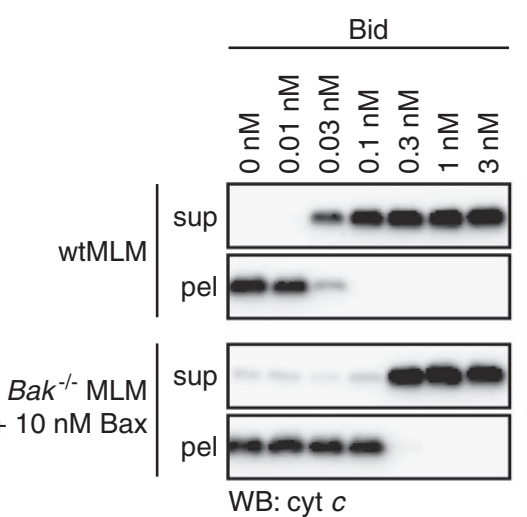

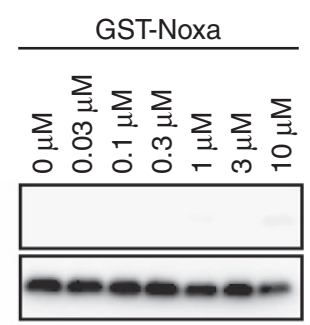

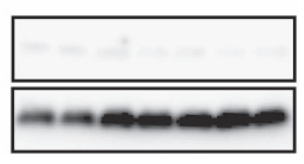

BH3 domain b

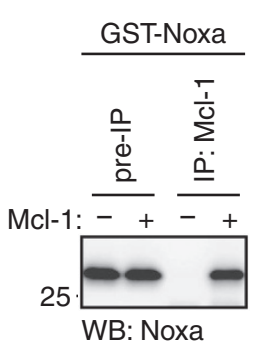

C

\begin{tabular}{|c|c|c|}
\hline \multirow{4}{*}{ Bid chimeras: } & & BH3 domain \\
\hline & BidNoxa $\quad 7$ & 76...SESQEDI IRECATQLRRFGDKLNFRIPPG... ${ }^{105}$ \\
\hline & Bid Noxa h0AA1 & ...SESQEDAARECATQLRRFGDKLNFRIPPG... \\
\hline & Bid Noxa h0AA2 & ...SESQEE AAVECATQLRRFGDKLNFRIPPG... \\
\hline \multirow[t]{4}{*}{ BH3 peptides: } & Noxa & 18PAELEVECATQLRRFGDKLNFRQKLL 44 \\
\hline & Noxa h0ll & PAEIIVECATQLRRFGDKLNFRQKLL \\
\hline & BidNoxa & SQEDIIRECATQLRRFGDKLNFRQKLL \\
\hline & BidNoxa h0AA & SQEDAARECATQLRRFGDKLNFRQKLL \\
\hline
\end{tabular}

d
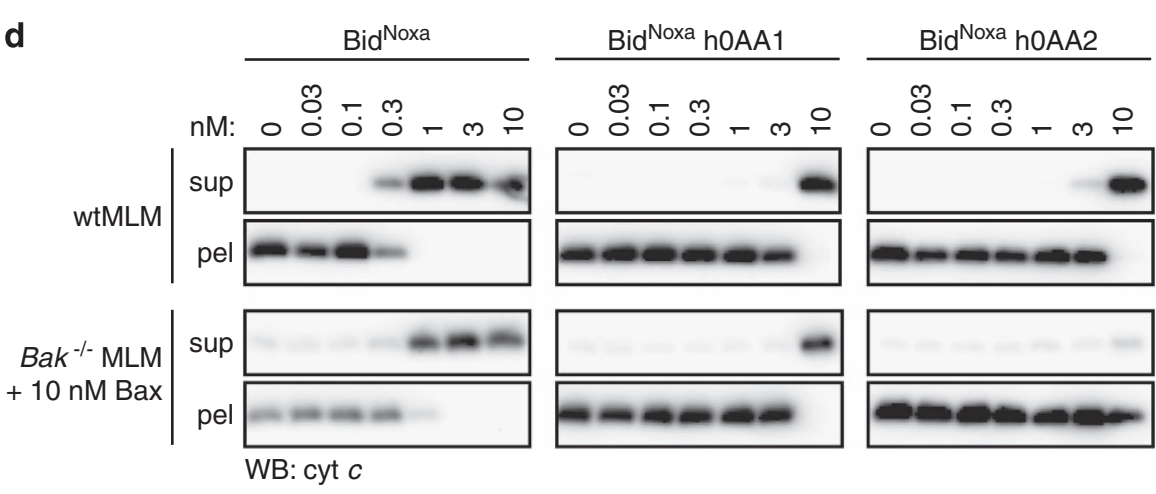

e
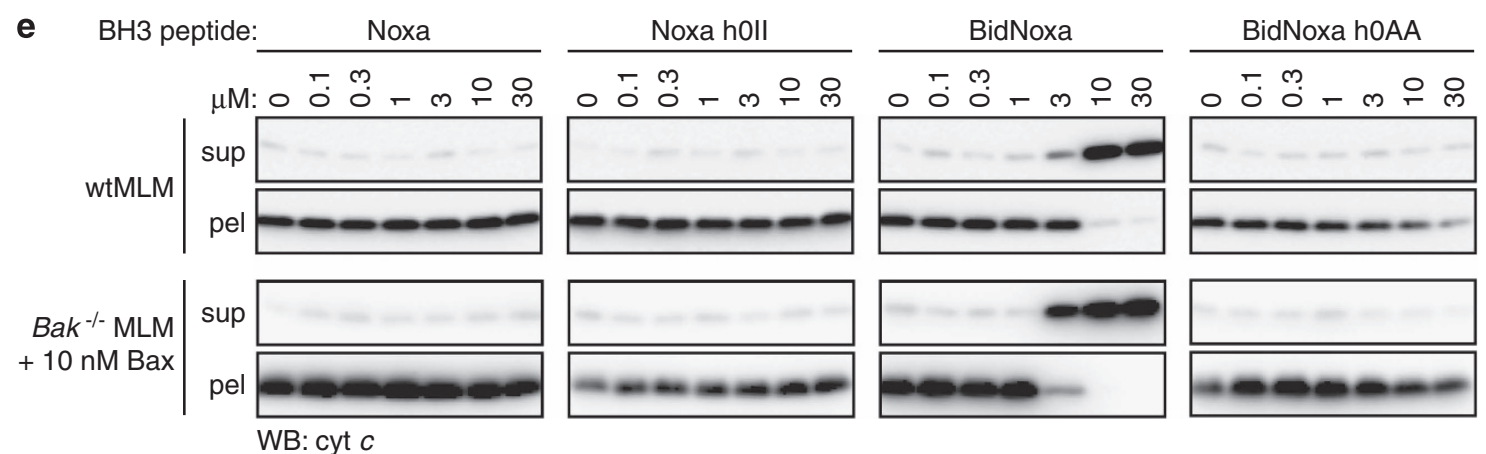

Figure 6 Noxa is not a direct activator of Bak or Bax. (a) GST-Noxa $\Delta$ C does not activate Bak or Bax. Wild-type MLM or Bak ${ }^{-1-}$ MLM plus $10 \mathrm{nM} \mathrm{Bax} \mathrm{were} \mathrm{treated} \mathrm{with} \mathrm{the}$ indicated Noxa reagents and tested for cytochrome $c$ release. (b) GST-Noxa $\Delta C$ binds to Mcl-1. GST-Noxa $\Delta C$ was incubated with Mcl-1 $\Delta N \Delta C$ at a $1: 1$ molar ratio in the presence of Bak ${ }^{-1-}$ MLM before immunoprecipitation of Mcl-1 and Western blotting for Noxa. (c) Sequences of Bid ${ }^{\text {Noxa }}$ chimera and Noxa BH3 peptide mutations. (d) Activator function of Bid ${ }^{\text {Noxa }}$ depends partially on the ho residues of Bid. The Bid ${ }^{\text {Noxa }}$ chimera variants were tested for activator function as in a. (e) Noxa peptide conversion to an activator depends on the h0 residues of Bid. The Noxa BH3 peptide variants were tested for activator function as in a. Blots are representative of two or more independent experiments 
185 and Bak 73-88) by PCR site-directed mutagenesis. The Bid backbone had a thrombin cleavage site in place of the caspase 8 cleavage site to allow one-step cleavage and purification ${ }^{30}$ and was cloned into pGEX-4T2 to add a C-terminal HA tag. Protein was expressed in Escherichia coli BL21 (DE3) induced with $1 \mathrm{mM}$ Isopropyl $\beta$-D-1-thiogalactopyranoside (IPTG) overnight at $18^{\circ} \mathrm{C}$. Bacteria were lysed in lysis buffer (phosphate buffered saline with $1 \mathrm{mM}$ EDTA, $10 \mu \mathrm{g} / \mathrm{ml}$ aprotinin and $10 \mu \mathrm{g} / \mathrm{ml}$ leupeptin), with $1 \mathrm{mM}$ dithiothreitol (DTT), $0.5 \mathrm{mM}$ phenylmethanesulfonyl fluoride, $266 \mu \mathrm{g} / \mathrm{ml}$ lysozyme and $37 \mu \mathrm{g} / \mathrm{ml}$ DNase I with a homogenizer (EmulsiFlex, Avestin, Ottawa, ON, Canada). The lysate was centrifuged and filtered, before incubation with glutathione beads (GE Healthcare Bio-Sciences AB, Uppsala, Sweden). Washed beads were incubated overnight at $4{ }^{\circ} \mathrm{C}$ with thrombin in $50 \mathrm{mM}$ Tris $\mathrm{pH} 8.0,150 \mathrm{mM} \mathrm{NaCl}$ and $5 \mathrm{mM} \mathrm{MgCl}$. Eluate was further purified by gel filtration (Superdex 75 , GE Healthcare Bio-Sciences AB) in Tris buffered saline (TBS; $20 \mathrm{mM}$ Tris pH 8.0 and $150 \mathrm{mM} \mathrm{NaCl}$ ) with $2 \mathrm{mM}$ DTT. Fractions were aliquoted and stored at $-80^{\circ} \mathrm{C}$.

Recombinant full-length human Bcl- $x_{\mathrm{L}}$ was cloned into PTYB1 vector to produce a fusion of $\mathrm{Bcl}-\mathrm{x}_{\mathrm{L}}$ with an intein/chitin binding protein, which can be removed to obtain $\mathrm{Bcl}-$ $X_{L}$ with vector encoded residues Gly-Ser-Ser at the $C$ terminus. Protein was expressed in ER2566 E. coli (New England Biolabs, Ipswich, MA, USA) induced with 0.5 mM IPTG overnight at $18^{\circ} \mathrm{C}$. Bacteria were lysed with a homogenizer in TEN buffer $(20 \mathrm{mM}$ Tris pH 8.0, $1 \mathrm{mM}$ EDTA, $500 \mathrm{mM} \mathrm{NaCl}$ ) with $10 \mathrm{mM} \mathrm{MgCl}_{2}, 25 \mu \mathrm{g} / \mathrm{ml}$ DNase I and protease inhibitor cocktail (Roche, Basel, Switzerland). CHAPS (1\%, Sigma-Aldrich, St Louis, MO, USA) was incubated with lysate for $30 \mathrm{~min}$ prior to centrifugation and filtration. Clarified lysate was passed through a column with chitin resin, which was then washed thoroughly with $0.2 \%$ CHAPS in TEN buffer. On-column cleavage of the intein tag was induced with $50 \mathrm{mM}$ DTT for at least $40 \mathrm{~h}$ at $4{ }^{\circ} \mathrm{C}$. Bcl- $\mathrm{x}_{\mathrm{L}}$ was eluted and further purified by gel filtration (Superdex 200) in TBS. Fractions were concentrated, aliquots flash frozen with liquid nitrogen and stored at $-80^{\circ} \mathrm{C}$. Bak $\Delta \mathrm{C} 22-\mathrm{HexH}$ is was produced by the Bax purification protocol described previously. ${ }^{24}$ The expression and purification of human Bax, mouse Mcl- $1 \Delta \mathrm{N} 151 \Delta \mathrm{C} 23$, human $\mathrm{Bcl}-\mathrm{x}_{\mathrm{L}} \Delta \mathrm{C} 25$ and human $\mathrm{Bcl}-2 \Delta \mathrm{C} 22$ has been described previously. 6 .

Human Noxa (residue 1-40) was cloned into pGEX 6P3 vector resulting in a C-terminal GST tag. Protein was expressed in E. coli BL21 (DE3) induced with $1 \mathrm{mM}$ IPTG for $3 \mathrm{~h}$ at $37^{\circ} \mathrm{C}$. Bacteria were homogenized in TBS-E (TBS with $1 \mathrm{mM}$ EDTA). The lysate was centrifuged and filtered before passing through a GST column. The column was then washed with TBS-E and bound proteins eluted with $10 \mathrm{mM}$ reduced glutathione (in TBS-E) then further purified by gel filtration (Superdex 75) in TBS.

Synthetic peptides based on human BH3 sequences were synthesized by Mimotopes (Notting Hill, VIC, Australia) and purified by reverse-phase HPLC to $>90 \%$ purity. Full peptide sequences are shown in Supplementary Figure 2. Most peptides have been published previously: Bid (34-mer) in Willis et al. ${ }^{18} \mathrm{Bim}$, Noxa, Bad and Hrk in Chen et al. ${ }^{6}$ Bak and Bax in Czabotar et al..$^{24}$ Noxa mutant peptide sequences are shown in Figure $5 \mathrm{c}$.

Mitochondrial cytochrome $c$ release. MLM were prepared from C57BL/6 wild-type or $\mathrm{Bak}^{-1-}$ mice as described. ${ }^{53}$ MLM were diluted to $1 \mathrm{mg} / \mathrm{ml}$ in MELB (100 mM KCl, $2.5 \mathrm{mM} \mathrm{MgCl}$, $100 \mathrm{mM}$ sucrose, $20 \mathrm{mM}$ HEPES/KOH pH 7.5, $5 \mathrm{mM}$ DTT) supplemented with protease inhibitor cocktail and $4 \mathrm{mg} / \mathrm{ml}$ pepstatin A (SigmaAldrich). Recombinant full-length Bax, Bid BH3 chimeras, GST-Noxa $\triangle \mathrm{C}$ and $\mathrm{BH} 3$ peptides were added as indicated, and samples incubated for $2 \mathrm{~h}$ at $37^{\circ} \mathrm{C}$. When chimeras were diluted significantly (e.g., dose-response experiments in Figures 3-5), binding of protein to tubes was minimized by the presence of $1 \%$ BSA in diluent (final 0.01 to $0.03 \%$ BSA). Similarly, peptides were diluted in $100 \%$ DMSO (final $1-3 \%$ DMSO on). Supernatant and pellet fractions were separated by centrifugation and analyzed by sodium dodecyl sulfate (SDS)-PAGE and Western blotting for cytochrome $c$.

SDS-PAGE and Western blotting. SDS-PAGE and Western blotting was performed as described. ${ }^{54}$ Primary antibodies used were anti-cytochrome $c 7 \mathrm{H} 8.2 \mathrm{C} 12$ mouse monoclonal (BD Biosciences, San Jose, CA, USA), anti-HA $16 \mathrm{~B} 12$ mouse monoclonal (Covance, Princeton, NJ, USA) or 3F10 rat monoclonal (Roche), anti-Mcl-1 19C4-15 rat monoclonal (WEHI mAb Facility, Bundoora, VIC, Australia ${ }^{55}$ ), anti-Bcl-x rabbit polyclonal (BD Biosciences), anti-Bcl-2 Bcl-2-100 mouse monoclonal (WEHI $\mathrm{mAb}$ Facility ${ }^{56}$ ), anti-Noxa $114 \mathrm{C} 307$ mouse monoclonal (Novus Biologicals, Littleton, CO, USA) and anti-Bak 4B5 rat monoclonal (WEHI mAb Facility ${ }^{57}$ ). Secondary antibodies were horseradish peroxidase-conjugated goat anti-mouse, goat anti-rabbit and goat anti-rat (Southern Biotech, Birmingham, AL, USA).

Quantitation of cytochrome $c$ release and dose-response analysis. Western blot images were quantitated by densitometry with ImageLab
4.1 software (Bio-Rad, Hercules, CA, USA). Percentage cytochrome $c$ release was determined independently from the supernatant and pellet densitometry (using Excel for Mac, Microsoft, Redmond, WA, USA) as follows. Percentage release in supernatant was calculated as the ratio of each density to the maximum density in the supernatant blot. The same calculation for pellet blots gave the percentage of cytochrome $c$ retained; percent release is then obtained by subtracting from $100 \%$. In cases where the densitometry on the pellet did not drop to zero (i.e., $100 \%$ cytochrome $c$ is not released) the supernatant percentages for that case were multiplied by densities of sup/(sup+pellet) for the dose corresponding to maximum cytochrome $c$ release. The two measures of cytochrome $c$ release (from supernatant and pellet) were imported into Prism 6 (Graphpad, La Jolla, CA, USA) and treated as two independent measures. Curves were fitted to the data using 'log(agonist) versus response' non-linear regression. 'Top' and 'Bottom' values were fixed at the average minimum and average maximum, respectively, of all blots in that experiment, and the $\log \left(\mathrm{EC}_{50}\right)$ and Hill Slope parameters were unconstrained.

Immunoprecipitation. For immunoprecipitation of $\mathrm{Bid} \mathrm{BH} 3$ chimeras with prosurvival Bcl-2 proteins, $40 \mathrm{nM}$ Bid chimeras were incubated with $40 \mathrm{nM} \mathrm{hBcl-} \mathrm{x}_{\mathrm{L}}$, $\mathrm{hBcl}-\mathrm{x}_{\mathrm{L}} \Delta \mathrm{C} 25, \mathrm{mMcl}-1 \Delta \mathrm{N} 151 \Delta \mathrm{C} 23$ or $\mathrm{hBcl}-2 \Delta \mathrm{C} 22$ in the presence of $1 \mathrm{mg} / \mathrm{ml}$ $\mathrm{Bak}^{-\prime}-\mathrm{MLM}$. After $1 \mathrm{~h}$ at $37^{\circ} \mathrm{C}$, samples were solubilized with $1 \%$ digitonin and immunoprecipitated as described ${ }^{57}$ using anti-Mcl-1 $14 \mathrm{C} 11$ rat monoclonal, ${ }^{58}$ anti$\mathrm{BCl}-\mathrm{X}_{\mathrm{L}} \mathrm{IC} 2$ rat monoclonal ${ }^{7}$ or anti-Bcl-2 $\mathrm{BCl}-2-100$ mouse monoclonal antibodies and Protein G Sepharose 4 fast flow (GE Healthcare Bio-Sciences AB).

Liposome permeabilization assay. Bak-mediated liposome assays were based on previously described methods. ${ }^{44}$ Liposomes were prepared by drying lipid mixes (46\% phosphatidylcholine, $25 \%$ phosphatidylethanolamine, $11 \%$ phosphatidylinositol, 10\% phosphatidylserine, $8 \%$ cardiolipin and 10\% 18:1 DGS-NTA(Ni) 1,2dioleoyl-sn-glycero-3-[(N-(5-amino-1 carboxypentyl) iminodiacetic acid)succinyl] (nickel salt)) in chloroform and $0.01 \%$ butylated hydroxytoluene under $\mathrm{N}_{2}$, and then resuspending in liposome buffer (10 mM HEPES pH 7.5 and $135 \mathrm{mM} \mathrm{KCl}$ ) containing $50 \mathrm{mM}$ 5(6)-carboxy-fluorescein. To remove excess free lipid and collect a uniform size liposome mixture the sample was passed over a polycarbonate membrane filter (diameter $19 \mathrm{~mm}$; pore size $0.1 \mu \mathrm{m}$ ). To remove unincorporated dye, the liposomes were passed through a PD10 desalting column. For each assay, liposomes were used at a final concentration of $2.5 \mathrm{mM}$ and the fluorescence of released self-quenching 5(6)-carboxy-fluorescein measured at an excitation wavelength of $485 \mathrm{~nm}$ and emission wavelength of $535 \mathrm{~nm}$.

\section{Conflict of Interest}

The authors declare no conflict of interest.

Acknowledgements. We thank Jerry Adams for critical reading of the manuscript; Stephanie Fennell, Tobias Kratina and Ahmad Wardak for technical assistance; Adeline Robin and Michael Roy for recombinant proteins; David Huang for ABT-737. The work was supported by grants from the National Health and Medical Research Council of Australia (no. 575559, no. 1016701 and no. 1041936), and the Association for International Cancer Research (no. 10-230), and operational infrastructure grants through the Victorian State Government Operational Infrastructure Support and the Australian Government NHMRC IRIISS.

1. Youle RJ, Strasser A. The BCL-2 protein family: opposing activities that mediate cell death. Nat Rev Mol Cell Biol 2008; 9: 47-59.

2. Czabotar PE, Lessene G, Strasser A, Adams JM. Control of apoptosis by the BCL-2 protein family: implications for physiology and therapy. Nat Rev Mol Cell Biol 2014; 15: $49-63$.

3. Shamas-Din A, Kale J, Leber B, Andrews DW. Mechanisms of action of Bcl-2 family proteins. Cold Spring Harb Perspect Biol 2013; 5: a008714.

4. Happo L, Strasser A, Cory S. BH3-only proteins in apoptosis at a glance. J Cell Sci 2012; 125: 1081-1087.

5. Letai AG, Bassik MC, Walensky LD, Sorcinelli MD, Weiler S, Korsmeyer SJ. Distinct BH3 domains either sensitize or activate mitochondrial apoptosis, serving as prototype cancer therapeutics. Cancer Cell 2002; 2: 183-192.

6. Chen L, Willis SN, Wei A, Smith BJ, Fletcher JI, Hinds MG et al. Differential targeting of prosurvival Bcl-2 proteins by their BH3-only ligands allows complementary apoptotic function. Mol Cell 2005; 17: 393-403.

7. Willis SN, Chen L, Dewson G, Wei A, Naik E, Fletcher Jl et al. Proapoptotic Bak is sequestered by $\mathrm{Mcl}-1$ and $\mathrm{Bcl}-\mathrm{xL}$, but not $\mathrm{Bcl}-2$, until displaced by $\mathrm{BH}$-only proteins. Genes Dev 2005; 19: 1294-1305.

8. Kuwana T, Bouchier-Hayes L, Chipuk JE, Bonzon C, Sullivan BA, Green DR et al. $\mathrm{BH} 3$ domains of $\mathrm{BH} 3$-only proteins differentially regulate Bax-mediated mitochondrial membrane permeabilization both directly and indirectly. Mol Cell 2005; 17: 525-535. 
9. Kim H, Rafiuddin-Shah M, Tu H-C, Jeffers JR, Zambetti GP, Hsieh JJ et al. Hierarchical regulation of mitochondrion-dependent apoptosis by BCL-2 subfamilies. Nat Cell Biol 2006; 8: $1348-1358$.

10. Fletcher JI, Meusburger S, Hawkins CJ, Riglar DT, Lee EF, Fairlie WD et al. Apoptosis is triggered when prosurvival Bcl-2 proteins cannot restrain Bax. Proc Natl Acad Sci USA 2008; 105: 18081-18087.

11. Llambi F, Moldoveanu T, Tait SWG, Bouchier-Hayes L, Temirov J, McCormick LL et al. A unified model of mammalian BCL-2 protein family interactions at the mitochondria. Mol Cell 2011; 44: 517-531.

12. Tse C, Shoemaker AR, Adickes J, Anderson MG, Chen J, Jin S et al. ABT-263: a potent and orally bioavailable Bcl-2 family inhibitor. Cancer Res 2008; 68: 3421-3428.

13. Souers AJ, Leverson JD, Boghaert ER, Ackler SL, Catron ND, Chen J et al. ABT-199, a potent and selective BCL-2 inhibitor, achieves antitumor activity while sparing platelets. Nat Med 2013; 19: 202-208.

14. Hinds MG, Smits C, Fredericks-Short R, Risk JM, Bailey M, Huang DCS et al. Bim, Bad and Bmf: intrinsically unstructured $\mathrm{BH} 3-$ only proteins that undergo a localized conformational change upon binding to prosurvival Bcl-2 targets. Cell Death Differ 2007; 14: 128-136.

15. Barrera-Vilarmau S, Obregón P, de Alba E. Intrinsic order and disorder in the bcl-2 member harakiri: insights into its proapoptotic activity. PLoS One 2011; 6: e21413.

16. Peng Z, Xue B, Kurgan L, Uversky VN. Resilience of death: intrinsic disorder in proteins involved in the programmed cell death. Cell Death Differ 2013; 20: 1257-1267.

17. Wilfling F, Weber A, Potthoff S, Vögtle F-N, Meisinger C, Paschen SA et al. BH3-only proteins are tail-anchored in the outer mitochondrial membrane and can initiate the activation of Bax. Cell Death Differ 2012; 19: 1328-1336.

18. Willis SN, Fletcher JI, Kaufmann T, van Delft MF, Chen L, Czabotar PE et al. Apoptosis initiated when BH3 ligands engage multiple Bcl-2 homologs, not Bax or Bak. Science 2007; 315: 856-859.

19. Billen LP, Kokoski CL, Lovell JF, Leber B, Andrews DW. Bcl-XL inhibits membrane permeabilization by competing with Bax. PLOS Biol 2008; 6: e147.

20. Dai H, Smith A, Meng XW, Schneider PA, Pang YP, Kaufmann SH. Transient binding of an activator $\mathrm{BH} 3$ domain to the Bak $\mathrm{BH} 3$-binding groove initiates Bak oligomerization. J Cell Biol 2011; 194: 39-48.

21. Ren D, Tu H-C, Kim H, Wang GX, Bean GR, Takeuchi O et al. BID, BIM, and PUMA are essential for activation of the BAX- and BAK-dependent cell death program. Science 2010; 330: $1390-1393$.

22. Villunger A, Labi V, Bouillet $P$, Adams JM, Strasser A. Can the analysis of BH3-only protein knockout mice clarify the issue of 'direct versus indirect' activation of Bax and Bak? Cell Death Differ 2011; 18: 1545-1546.

23. Du H, Wolf J, Schafer B, Moldoveanu T, Chipuk JE, Kuwana T. BH3 domains other than Bim and Bid can directly activate Bax/Bak. J Biol Chem 2011; 286: 491-501.

24. Czabotar PE, Westphal D, Dewson G, Ma S, Hockings C, Fairlie WD et al. Bax crystal structures reveal how $\mathrm{BH} 3$ domains activate $\mathrm{Bax}$ and nucleate its oligomerization to induce apoptosis. Cell 2013; 152: 519-531.

25. Sarosiek KA, Chi X, Bachman JA, Sims JJ, Montero J, Patel L et al. BID preferentially activates BAK while BIM preferentially activates BAX, affecting chemotherapy response. $\mathrm{Mol}$ Cell 2013; 51: 751-765.

26. Cartron P-FF, Gallenne T, Bougras G, Gautier F, Manero F, Vusio P et al. The first alpha helix of Bax plays a necessary role in its ligand-induced activation by the $\mathrm{BH}$-only proteins Bid and PUMA. Mol Cell 2004; 16: 807-818.

27. Dai H, Pang YP, Ramirez-Alvarado M, Kaufmann SH. Evaluation of the BH3-only protein Puma as a direct Bak activator. J Biol Chem 2014; 289: 89-99.

28. Certo M, Del Gaizo Moore V, Nishino M, Wei G, Korsmeyer SJ, Armstrong SA et al. Mitochondria primed by death signals determine cellular addiction to antiapoptotic BCL-2 family members. Cancer Cell 2006; 9: 351-365.

29. Merino D, Giam M, Hughes PD, Siggs OM, Heger K, O'Reilly LA et al. The role of BH3-only protein Bim extends beyond inhibiting Bcl-2-like prosurvival proteins. J Cell Biol 2009; 186 355-362.

30. Ahsen von O, Renken C, Perkins G, Kluck RM, Bossy-Wetzel E, Newmeyer DD. Preservation of mitochondrial structure and function after Bid- or Bax-mediated cytochrome $\mathrm{C}$ release. J Cell Biol 2000; 150: 1027-1036.

31. Sattler M, Liang H, Nettesheim DG, Meadows RP, Harlan JE, Eberstadt M et al. Structure of Bcl-xL-Bak peptide complex: recognition between regulators of apoptosis. Science 1997; 275: 983-986

32. Chou JJ, Li H, Salvesen GS, Yuan J, Wagner G. Solution structure of BID, an intracellular amplifier of apoptotic signaling. Cell 1999; 96: 615-624.

33. Lovell JF, Billen LP, Bindner S, Shamas-Din A, Fradin C, Leber B et al. Membrane binding by tBid initiates an ordered series of events culminating in membrane permeabilization by Bax. Cell 2008; 135: 1074-1084.

34. García-Sáez AJ, Ries J, Orzáez M, Pérez-Payá E, Schwille P. Membrane promotes tBID interaction with BCL(XL). Nat Struct Mol Biol 2009; 16: 1178-1185.

35. Bleicken S, García-Sáez AJ, Conte E, Bordignon E. Dynamic interaction of cBid with detergents, liposomes and mitochondria. PLoS One 2012; 7: e35910.
36. Zha J, Weiler S, Oh KJ, Wei MC, Korsmeyer SJ. Posttranslational N-myristoylation of BID as a molecular switch for targeting mitochondria and apoptosis. Science 2000; 290: 1761-1765.

37. Walensky LD, Pitter K, Morash J, Oh KJ, Barbuto S, Fisher JK et al. A stapled BID BH3 helix directly binds and activates BAX. Mol Cell 2006; 24: 199-210.

38. Renault TT, Floros KV, Chipuk JE. BAK/BAX activation and cytochrome $c$ release assays using isolated mitochondria. Methods 2013; 61: 146-155.

39. Moldoveanu T, Grace CR, Llambi F, Nourse A, Fitzgerald P, Gehring K et al. BID-induced structural changes in BAK promote apoptosis. Nat Struct Mol Biol 2013; 20: 589-597.

40. Uren RT, Dewson G, Chen L, Coyne SC, Huang DCS, Adams JM et al. Mitochondrial permeabilization relies on $\mathrm{BH} 3$ ligands engaging multiple prosurvival $\mathrm{Bcl}-2$ relatives, not $\mathrm{Bak}$. $J$ Cell Biol 2007; 177: 277-287.

41. Wei MC, Lindsten T, Mootha VK, Weiler S, Gross A, Ashiya M et al. tBID, a membranetargeted death ligand, oligomerizes BAK to release cytochrome c. Genes Dev 2000; 14 : 2060-2071.

42. Ruffolo SC, Shore GC. BCL-2 selectively interacts with the BID-induced open conformer of BAK, inhibiting BAK auto-oligomerization. J Biol Chem 2003; 278: 25039-25045.

43. Oh KJ, Barbuto S, Pitter K, Morash J, Walensky LD, Korsmeyer SJ. A membrane-targeted BID BCL-2 homology 3 peptide is sufficient for high potency activation of BAX in vitro. J Biol Chem 2006; 281: 36999-37008.

44. Oh KJ, Singh P, Lee K, Foss K, Lee S, Park M et al. Conformational changes in BAK, a poreforming proapoptotic $\mathrm{Bcl}-2$ family member, upon membrane insertion and direct evidence for the existence of $\mathrm{BH} 3-\mathrm{BH} 3$ contact interface in BAK homo-oligomers. J Biol Chem 2010; 285 : 28924-28937.

45. Terrones O, Etxebarria A, Landajuela A, Landeta O, Antonsson B, Basañez G. BIM and tBID are not mechanistically equivalent when assisting $B A X$ to permeabilize bilayer membranes. J Biol Chem 2008; 283: 7790-7803.

46. Walensky LD, Kung AL, Escher I, Malia TJ, Barbuto S, Wright RD et al. Activation of apoptosis in vivo by a hydrocarbon-stapled BH3 helix. Science 2004; 305: 1466-1470.

47. Rogers JM, Oleinikovas V, Shammas SL, Wong CT, De Sancho D, Baker CM et al. Interplay between partner and ligand facilitates the folding and binding of an intrinsically disordered protein. Proc Natl Acad Sci USA 2014; 111: 15420-15425.

48. Gong X-M, Choi J, Franzin CM, Zhai D, Reed JC, Marassi FM. Conformation of membraneassociated proapoptotic tBid. J Biol Chem 2004; 279: 28954-28960.

49. Yao Y, Bobkov AA, Plesniak LA, Marassi FM. Mapping the interaction of pro-apoptotic tBID with pro-survival BCL-XL. Biochemistry 2009; 48: 8704-8711.

50. Rautureau GJP, Day CL, Hinds MG. Intrinsically disordered proteins in bcl-2 regulated apoptosis. Int J Mol Sci 2010; 11: 1808-1824.

51. Wang $Y$, Tjandra N. Structural insights of tBid, the caspase-8-activated Bid, and its BH3 domain. J Biol Chem 2013; 288: 35840-35851.

52. Brouwer JM, Westphal D, Dewson G, Robin AY, Uren RT, Bartolo R et al. Bak core and latch domains separate during activation, and freed core domains form symmetric homodimers. Mol Cell 2014; 55: 938-946.

53. Uren RT, Dewson G, Bonzon C, Lithgow T, Newmeyer DD, Kluck RM. Mitochondrial release of pro-apoptotic proteins: electrostatic interactions can hold cytochrome c but not Smac/ DIABLO to mitochondrial membranes. J Biol Chem 2005; 280: 2266-2274.

54. Tran VH, Bartolo R, Westphal D, Alsop A, Dewson G, Kluck RM. Bak apoptotic function is not directly regulated by phosphorylation. Cell Death Dis 2013; 4: e452.

55. Lee EF, Czabotar PE, van Delft MF, Michalak EM, Boyle MJ, Willis SN et al. A novel BH3 ligand that selectively targets $\mathrm{Mcl}-1$ reveals that apoptosis can proceed without $\mathrm{Mcl}-1$ degradation. J Cell Biol 2008; 180: 341-355.

56. Pezzella F, Tse AG, Cordell JL, Pulford KA, Gatter KC, Mason DY. Expression of the bcl-2 oncogene protein is not specific for the 14;18 chromosomal translocation. Am J Pathol 1990; 137: 225-232.

57. Dewson G, Kratina T, Sim HW, Puthalakath H, Adams JM, Colman PM et al. To trigger apoptosis, Bak exposes its $\mathrm{BH} 3$ domain and homodimerizes via $\mathrm{BH}$ :groove interactions. Mol Cell 2008; 30: 369-380.

58. Banerjee A, Grumont R, Gugasyan R, White C, Strasser A, Gerondakis S. NF-kappaB1 and $\mathrm{c}$-Rel cooperate to promote the survival of TLR4-activated $\mathrm{B}$ cells by neutralizing Bim via distinct mechanisms. Blood 2008; 112: 5063-5073.

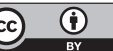

Cell Death and Disease is an open-access journal published by Nature Publishing Group. This work is licensed under a Creative Commons Attribution 4.0 International License. The images or other third party material in this article are included in the article's Creative Commons license, unless indicated otherwise in the credit line; if the material is not included under the Creative Commons license, users will need to obtain permission from the license holder to reproduce the material. To view a copy of this license, visit http://creativecommons.org/licenses/by/4.0/ 